\title{
Nutrient partitioning and response to insulin challenge at different planes of nutrition during lactation in goats of high $v s$. low milk production potential
}

\author{
P.B. Cronjé\#, M. de Jager and E. Vlok \\ Department of Animal and Wildlife Sciences, University of Pretoria, Pretoria 0002, South Africa
}

\begin{abstract}
The aim of this experiment was to determine the effect of genetic selection for milk production on nutrient partitioning at a high $v s$. a low plane of nutrition. Twelve Indigenous goat does and eight Saanen $\mathrm{x}$ Indigenous crossbred does were allocated to either a basal diet formulated to provide energy for maintenance or the basal diet supplemented with maize so as to maintain a plasma glucose concentration of $3.5 \mathrm{mmol} / \mathrm{l}$ throughout lactation. Milk yield was not reduced by the low plane of nutrition in either genotype. The sustained rate of milk production at the low level of nutrition was achieved by increased mobilisation of endogenous nutrients from body reserves, evidenced as a greater loss of body mass at the low plane of nutrition in both breeds. The Saanen crossbred genotype, which produced twice as much milk as the Indigenous genotype, lost $19 \%$ of initial mass by week 10 of lactation, whereas mass losses in the indigenous goat never exceeded 7\%, with the result that repletion of initial (week one) mass was achieved by week six of lactation. Plasma glucose concentrations were depressed to a smaller extent by insulin in the Saanen crossbred than in the Indigenous goat at weeks 3, 7 and 11 of lactation. Although there was evidence for a genotype $\mathrm{x}$ nutrition interaction during early lactation, this did not persist throughout lactation. The majority of data derived from this study indicates that the two genotypes reacted in a similar manner to plane of nutrition, with the main differences between milk yield potential being occasioned by differences in the extent of mobilisation of endogenous body reserves mediated by differences in insulin sensitivity.
\end{abstract}

Keywords: lactation, insulin, glucose, ruminant, genotype, nutrition

\#Author to whom correspondence should be addressed. E-mail: pbcronje@ postino.up.ac.za

\section{Introduction}

Differences in the partitioning of nutrients represent the most important mechanism that determines differences in production rate in animals fed at equal planes of nutrition. Genetic selection appears to alter nutrient partitioning such that the selected characteristic is "protected" against nutritional deprivation at the expense of other body functions/tissues (Lobley, 1998). In times of nutrient scarcity, this re-direction of priorities for nutrient partitioning may result in depletion of endogenous reserves and lower reproduction rates in animals selected for high rates of milk production or muscle deposition. The effects of genetic selection on nutrient partitioning are of great importance in the case of grazing ruminants in environments subject to seasonal and periodic changes in nutrient availability. In such environments, the ideal genotype would be one that has the potential to attain high production yields (e.g. milk production) when the supply of nutrients is non-limiting, but which is able to adapt nutrient partitioning when nutrient supply is constrained in such a way that essential functions are not compromised. The issue of whether genetic selection for production traits evokes 'competition' between different body functions or whether homeorhetic mechanisms over-ride genetic priorities to 'co-ordinate' nutrient partitioning (see Bauman, 2000) is still unresolved. The 'competition' model would suggest that genetic selection increases nutrient partitioning to productive functions at the expense of the capacity to adapt to low planes of nutrition. The implication of this is that genetic selection should aim at placing an upper limit on production yields such that the mean yield does not exceed that which can be sustained by the long-term mean nutrient supply. On the other hand, the 'coordination' model suggests that genotype $\mathrm{x}$ nutrition interactions exist which enable animals to adapt to plane of nutrition irrespective of their genetic potential. The implication of this is that production rate of African indigenous livestock breeds could be rapidly increased by selection under intensive feeding conditions or by crossbreeding with exotic high-producing breeds without negative consequences for reproductive efficiency.

The physiological basis of responses to genetic selection is poorly quantified, and concern has been expressed that genetic increases in economically important production traits such as milk yield may have been achieved at the expense of the ability of the animal to adapt to low planes of nutrition (Cronjé, 2000). There is increasing pressure to increase the productivity of indigenous African livestock breeds by cross-breeding with exotic "high-producing" breeds, but the consequences of such genetic improvement on the capacity of the animal to adapt to variable and marginal planes of nutrition characteristic of many African farming systems has not been adequately investigated. In this study, the Indigenous South African goat was compared with a crossbreed of higher milk yield potential (Indigenous x Saanen milk goat). The study was designed to determine whether these two genotypes differed in respect of their ability to adapt milk production in accordance with plane of nutrition. 


\section{Materials and methods}

Twelve Indigenous goat does and eight Saanen x Indigenous crossbred does aged 1.5-3 years were used in the experiment. Where multiple kids were born, the surplus kids were removed and hand-reared, so that all does suckled only one kid. Does were weighed on the first Monday after parturition, and feeding of the experimental diet commenced the following day. Within each genotype, does were randomly allocated to one of two dietary treatments: a basal diet or a supplemented diet. The basal diet consisted of a commercial pelleted feed and was fed according to National Research Council (1981) energy requirements for maintenance $\left(0.424 \mathrm{MJ} \mathrm{ME} / \mathrm{kg} \mathrm{W}^{0.75}\right)$, but no allowance was made for energy requirements for milk production. The feed contained $96.8 \mathrm{~g} / \mathrm{kg}$ crude protein and $8.71 \mathrm{MJ} / \mathrm{kg} \mathrm{ME}$. The amount of basal diet fed was adjusted according to body-mass on a weekly basis. The animals allocated to the supplemented diet treatment received the basal diet as described above, and a supplement of maize coated with a commercial mixture of molasses, urea and minerals. The amount of supplement offered was adjusted on a weekly basis according to individual plasma glucose concentrations so as to maintain a concentration of $3.50 \mathrm{mmol} / \mathrm{l}$ throughout lactation. The supplementary maize was initially fed at a level of $250 \mathrm{~g} / \mathrm{d} / \mathrm{animal}$ but was increased in increments of $25 \mathrm{~g} / \mathrm{d}$ when glucose concentrations were lower than $3.25 \mathrm{mmol} / \mathrm{l}$. The amount fed was decreased in the same fashion when concentrations exceeded $3.75 \mathrm{mmol} / \mathrm{l}$. The experiment was terminated after 12 weeks.

Weekly blood samples were taken on the same day and at the same time by jugular venipuncture into tubes containing EDTA as anti-coagulant (1mg EDTA /ml blood) and centrifuged at $3000 \mathrm{x} g$ to separate the plasma which was then stored at $-15^{\circ} \mathrm{C}$ until analysis for glucose concentration (modified enzymatic Trinder method, SA Institute for Medical Research, Sandringham, South Africa), urea (Berthelot method, Reagents Applications Inc., San Diego, California) and cholesterol (cholesterol esterase method, South African Institute for Medical Research, Sandringham, South Africa).

Does were milked fortnightly. After being separated from their kids, the does were injected intramuscularly with 1 IU of synthetic oxytocin (Fentocin; Phenix (Pty) Ltd, Johannesburg, South Africa) in 1ml of sterile saline solution to elicit milk ejection, and milked by hand. The first milking was done in order to empty the udder. Milking was then repeated after 4 hours and daily milk production rates estimated from this. Representative sub-samples were preserved with dichromate and analysed for fat, protein and lactose content by infrared analysis (System 400 Analyser, Foss Electric, Hillerod, Denmark).

Insulin tolerance tests were conducted during weeks 3, 7 and 11 of lactation. Jugular catheters (ID $0.86 \mathrm{~mm}$, OD $1.27 \mathrm{~mm}$; Dural Plastics, N.S.W., Australia) were inserted one day prior to the sampling period. A solution of $100 \mathrm{IU}$ heparin $/ \mathrm{ml}$ isotonic saline solution $(0.9 \% \mathrm{NaCl})$ was used to maintain catheter patency overnight, and solution of $25 \mathrm{IU}$ heparin/ml was used during repetitive sampling. On the following day, a single dose of insulin (0.1 IU/ kg BW) in saline solution was administered intravenously over a 30 second period. Blood samples were taken prior to the insulin injection and at the following times thereafter ( $\mathrm{min}): 15,30,45,60,120$. Blood samples were processed and analysed as described above.

Because of missing observations, a multivariate analysis was not feasible, and data were analysed within week using a general linear model (SAS, 1990) with diet and breed as predictor variables, as well as their interactions. The effect of tolerance test period (weeks 3,7 and 11) was, however, included in the model as a repeated measure because the observations were made on the same set of animals in each of the periods.

\section{Results}

Diet had little effect on milk production traits, the predominant effect being that of breed (Table 1). Milk production rates of Saanen crossbred does were higher $(\mathrm{P}<0.01)$ than that of Indigenous does throughout lactation, and differences in the production rates of milk fat, lactose and protein showed a similar pattern (Table 2). The response of milk production rate to plane of nutrition differed between genotypes during week 1 of lactation (Table 1): milk production was unaltered by plane of nutrition in the Indigenous goat $(\mathrm{P}>0.05)$, while in the Saanen crossbred, milk production was decreased $(\mathrm{P}<0.05)$ in response to the low plane of nutrition (basal diet). It was, however, still $42 \%$ higher than that recorded for the Indigenous genotype $(\mathrm{P}<0.01)$. Similar diet $\mathrm{x}$ genotype interactions $(\mathrm{P}<0.05)$ were recorded during week 1 of lactation for milk fat and lactose concentrations (Table 1). Milk production was not influenced by plane of nutrition in either genotype for any of the other weeks of lactation $(\mathrm{P}>0.05)$. 
Table 1 Main effects of diet, breed and diet $\mathrm{x}$ breed interaction on milk production traits of Indigenous and Saanen $\mathrm{x}$ Indigenous crossbred goats during weeks $1,3,5,7,9$ and 11 of lactation

\begin{tabular}{|c|c|c|c|c|c|c|c|c|c|c|c|c|}
\hline \multirow[b]{2}{*}{ Week } & \multicolumn{3}{|c|}{ Milk yield ( $\mathrm{g} / \mathrm{d})$} & \multicolumn{3}{|c|}{ Milk fat $(\mathrm{g} / \mathrm{d})$} & \multicolumn{3}{|c|}{ Milk lactose $(\mathrm{g} / \mathrm{d})$} & \multicolumn{3}{|c|}{ Milk protein $(\mathrm{g} / \mathrm{d})$} \\
\hline & Diet & Breed & $\begin{array}{l}\text { Diet } x \\
\text { Breed }\end{array}$ & Diet & Breed & $\begin{array}{l}\text { Diet } x \\
\text { Breed }\end{array}$ & Diet & Breed & $\begin{array}{l}\text { Diet } x \\
\text { Breed }\end{array}$ & Diet & Breed & $\begin{array}{l}\text { Diet } x \\
\text { Breed }\end{array}$ \\
\hline 1 & NS & $* *$ & $*$ & NS & ** & $*$ & NS & ** & $*$ & NS & + & NS \\
\hline 3 & NS & $* *$ & NS & NS & $*$ & NS & NS & $*$ & NS & NS & $*$ & NS \\
\hline 5 & NS & $* *$ & NS & NS & $* *$ & NS & NS & $* *$ & NS & NS & $* *$ & NS \\
\hline 7 & NS & $* *$ & NS & NS & NS & NS & $*$ & $*$ & NS & NS & NS & NS \\
\hline 9 & NS & $* *$ & NS & $*$ & $* *$ & NS & NS & $* *$ & NS & NS & $*$ & NS \\
\hline 11 & NS & $* *$ & NS & NS & $*$ & NS & NS & $* *$ & NS & NS & $*$ & NS \\
\hline
\end{tabular}

${ }^{+} \mathrm{P}<0.06 ;{ }^{*} \mathrm{P}<0.05 ;{ }^{* *} \mathrm{P}<0.01 ; \mathrm{NS}$, not significant

Table 2 Milk production traits of Indigenous and Saanen x Indigenous crossbred goats

\begin{tabular}{|c|c|c|c|c|c|c|c|c|}
\hline \multirow[b]{2}{*}{ Week } & \multicolumn{2}{|c|}{$\underline{\text { Milk Production }(\mathrm{g} / \mathrm{d})}$} & \multicolumn{2}{|c|}{ Milk Fat $(\mathrm{g} / \mathrm{d})$} & \multicolumn{2}{|c|}{ Milk Protein $(\mathrm{g} / \mathrm{d})$} & \multicolumn{2}{|c|}{ Milk lactose $(\mathrm{g} / \mathrm{d})$} \\
\hline & Indigenous & Saanen & Indigenous & Saanen & Indigenous & Saanen & Indigenous & Saanen \\
\hline 1 & $710^{\mathrm{a}}(42)$ & $1194^{\mathrm{b}}(52)$ & $47^{\mathrm{a}}(6)$ & $81^{\mathrm{b}}(6)$ & $31(2)$ & $38(3)$ & $39^{\mathrm{a}}(3)$ & $59^{\mathrm{b}}(3)$ \\
\hline 3 & $598^{a}(106)$ & $1135^{\mathrm{b}}(150)$ & $37^{c}(6)$ & $66^{\mathrm{d}}(9)$ & $21^{\mathrm{c}}(4)$ & $37^{\mathrm{d}}(5)$ & $34^{\mathrm{c}}(5)$ & $55^{\mathrm{d}}(7)$ \\
\hline 5 & $480^{a}(74)$ & $1536^{\mathrm{b}}(95)$ & $35^{\mathrm{a}}(6)$ & $96^{\mathrm{b}}(7)$ & $18^{\mathrm{a}}(2)$ & $45^{\mathrm{b}}(3)$ & $27^{\mathrm{a}}(4)$ & $74^{\mathrm{b}}(5)$ \\
\hline 7 & $608^{\mathrm{a}}(79)$ & $1211^{\mathrm{b}}(100)$ & $49(7)$ & $66(8)$ & $30(4)$ & 35 (4) & $38^{\mathrm{c}}(5)$ & $58^{\mathrm{d}}(5)$ \\
\hline 9 & $380^{\mathrm{a}}(64)$ & $951^{\mathrm{b}}(80)$ & $28^{\mathrm{a}}(5)$ & $50^{\mathrm{b}}(5)$ & $17^{c}(3)$ & $26^{\mathrm{d}}(3)$ & $21^{a}(5)$ & $45^{\mathrm{b}}(5)$ \\
\hline 11 & $384^{\mathrm{a}}(63)$ & $947^{\mathrm{b}}(75)$ & $29^{c}(6)$ & $48^{\mathrm{d}}(7)$ & $20^{c}(3)$ & $30^{\mathrm{d}}(4)$ & $20^{\mathrm{a}}(3)$ & $43^{\mathrm{b}}(4)$ \\
\hline
\end{tabular}

$\overline{a, b, c, d}$ Means in the same row and within the same variable with different superscripts differ significantly: ${ }^{a, b}(\mathrm{P}<0.01),{ }^{c, d}(P<0.05)$ Standard errors are given in parentheses.

Because the Saanen crossbred is a larger genotype than the indigenous goat (e.g. $39.5 \mathrm{vs.} 23.2 \mathrm{~kg}$ live mass at week 1), masses were expressed as a percentage of that recorded during the first week postpartum to facilitate comparison. Expressed on this basis, masses differed $(\mathrm{P}<0.01)$ between genotypes from weeks 5-12 (Table 3).

Table 3 Main effects of diet, breed and diet x breed interaction on growth traits of Indigenous and Saanen x Indigenous crossbred goats during various weeks of lactation

\begin{tabular}{|c|c|c|c|c|c|c|c|c|c|}
\hline \multirow[b]{2}{*}{ Week } & \multicolumn{3}{|c|}{ Kid Mass (kg) } & \multicolumn{3}{|c|}{ Doe mass (kg) } & \multicolumn{3}{|c|}{$\begin{array}{c}\text { Doe mass } \\
\text { (\% of mass during week } \\
1 \text { post-partum) } \\
\end{array}$} \\
\hline & Diet & Breed & $\begin{array}{l}\text { Diet } \mathrm{x} \\
\text { Breed } \\
\end{array}$ & Diet & Breed & $\begin{array}{l}\text { Diet } x \\
\text { Breed }\end{array}$ & Diet & Breed & $\begin{array}{l}\text { Diet } x \\
\text { Breed }\end{array}$ \\
\hline 0 & NS & $*$ & NS & NS & $* *$ & NS & - & - & - \\
\hline 1 & NS & $* *$ & $*$ & NS & $* *$ & NS & - & - & - \\
\hline 2 & NS & $* *$ & + & NS & $* *$ & NS & NS & $*$ & $*$ \\
\hline 3 & NS & $* *$ & NS & NS & $* *$ & NS & NS & NS & NS \\
\hline 4 & NS & $* *$ & NS & NS & $* *$ & NS & $*$ & NS & NS \\
\hline 5 & NS & $* *$ & NS & NS & $* *$ & NS & + & $* *$ & NS \\
\hline 6 & NS & $* *$ & NS & NS & $* *$ & NS & $* *$ & $* *$ & NS \\
\hline 7 & NS & $* *$ & NS & $*$ & $* *$ & NS & $* *$ & $* *$ & NS \\
\hline 8 & NS & $* *$ & NS & $*$ & $* *$ & NS & $* *$ & $* *$ & NS \\
\hline 9 & NS & $* *$ & NS & $*$ & $* *$ & NS & $* *$ & $* *$ & NS \\
\hline 10 & NS & $* *$ & NS & $*$ & $* *$ & NS & $* *$ & $* *$ & NS \\
\hline 11 & NS & $* *$ & NS & $*$ & $* *$ & NS & $* *$ & $* *$ & NS \\
\hline 12 & NS & $* *$ & NS & NS & $* *$ & NS & $*$ & $* *$ & NS \\
\hline
\end{tabular}




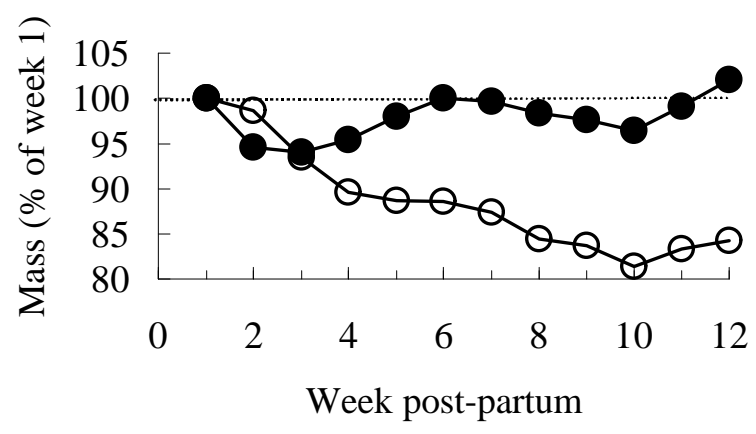

Figure 1 Mean live weight of Indigenous $(\bullet)$ and Saanen crossbred $(\mathrm{O})$ goats during lactation.

Mean body mass of Indigenous does (Figure 1) showed an initial decline, which coincided with peak lactation (weeks 2-3), and then increased to the extent that a mass equivalent to initial body mass was attained by week six of lactation. In contrast, mean body mass of the Saanen crossbred genotype decreased during lactation and was $16 \%$ less at weaning than during week one of lactation. Animals fed the basal diet weighed less than those fed the supplemented diet (Figure 2), and differences were significant $(\mathrm{P}<0.06)$ from weeks 4-12 (Table 3).

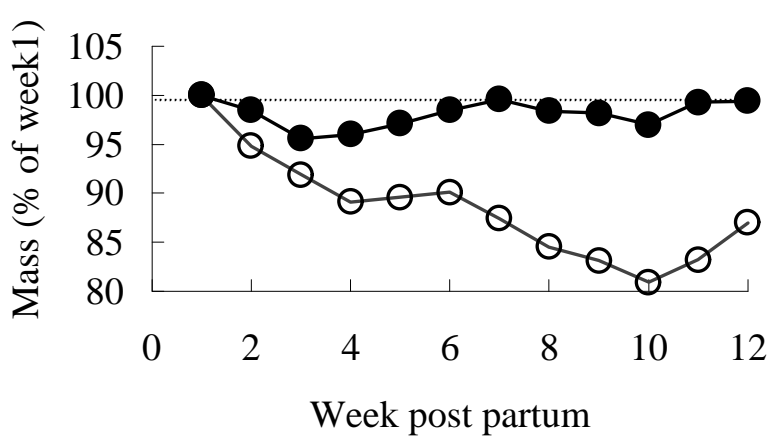

Figure 2 Mean live weights during lactation of goats fed a basal diet $(\mathrm{O})$ or a basal diet supplemented to maintain a mean plasma glucose concentration of $3.5 \mathrm{mmol} / \mathrm{l}(\bullet)$.

Mean body masses of kids are shown in Figure 3. Kid masses differed between genotypes $(\mathrm{P}<0.05)$ at all weeks of lactation, but the diet fed to the does had no effect $(\mathrm{P}>0.05)$ on the masses of their kids (Table 3).

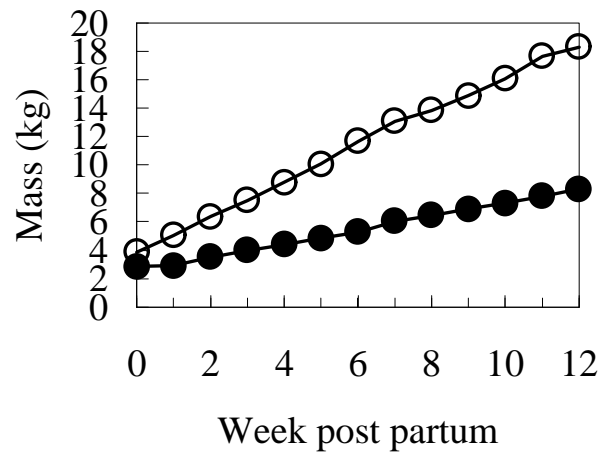

Figure 3 Mean live weights from birth to weaning of kids born to Indigenous $(\bullet)$ and Saanen crossbred (O) dams. 
The increase in mean kid mass over time was linear. Regression equations were: mass of Indigenous kids $(\mathrm{kg})=$ $2.58+0.475 \mathrm{x}$ week postpartum $\left(\mathrm{r}^{2}=0.99\right)$; mass of Saanen crossbred kids $(\mathrm{kg})=3.94+1.229 \mathrm{x}$ week postpartum $\left(\mathrm{r}^{2}\right.$ $=0.99)$. Comparison of these equations shows that while the mean birth mass of Saanen crossbred kids was $53 \%$ greater than that of the Indigenous kids, growth rates were $159 \%$ greater.

Table 4 Main effects of diet, breed and diet $x$ breed interaction on plasma concentrations of urea, glucose and cholesterol in Indigenous and Saanen $x$ Indigenous crossbred goats during various weeks of lactation

\begin{tabular}{|c|c|c|c|c|c|c|c|c|c|}
\hline \multirow[b]{2}{*}{ Week } & \multicolumn{3}{|c|}{ Urea (mg/dl) } & \multicolumn{3}{|c|}{ Glucose $(\mathrm{mmol} / \mathrm{l})$} & \multicolumn{3}{|c|}{ Cholesterol (mg/dl) } \\
\hline & Diet & Breed & $\begin{array}{l}\text { Diet } \mathrm{x} \\
\text { Breed }\end{array}$ & Diet & Breed & $\begin{array}{l}\text { Diet } x \\
\text { Breed }\end{array}$ & Diet & Breed & $\begin{array}{l}\text { Diet } x \\
\text { Breed }\end{array}$ \\
\hline 1 & NS & $* *$ & $\mathrm{NS}$ & NS & $* *$ & NS & $* *$ & NS & $\mathrm{NS}$ \\
\hline 2 & $*$ & $* *$ & + & $*$ & $* *$ & NS & NS & NS & $*$ \\
\hline 3 & NS & $*$ & NS & NS & $* *$ & NS & NS & $*$ & NS \\
\hline 4 & NS & $* *$ & NS & NS & $* *$ & NS & NS & $* *$ & + \\
\hline 5 & NS & $* *$ & NS & NS & $* *$ & NS & NS & + & NS \\
\hline 6 & NS & $* *$ & NS & NS & $* *$ & NS & NS & $*$ & NS \\
\hline 7 & $*$ & $* *$ & $*$ & NS & $*$ & NS & NS & + & NS \\
\hline 8 & NS & $* *$ & NS & NS & $*$ & NS & NS & $*$ & NS \\
\hline 9 & NS & $* *$ & NS & NS & + & NS & NS & $*$ & NS \\
\hline 10 & NS & $* *$ & NS & NS & $*$ & NS & NS & $* *$ & NS \\
\hline 11 & NS & $* *$ & NS & NS & $* *$ & NS & NS & NS & NS \\
\hline 12 & NS & $* *$ & NS & $*$ & NS & NS & NS & NS & NS \\
\hline
\end{tabular}

Although plasma glucose concentrations for the supplemented diet were only statistically higher $(\mathrm{P}<0.05)$ during weeks 2 and 12 of lactation (Table 4), they tended to be higher during weeks $4,6,7$, and $8(\mathrm{P}=0.09,0.13,0.15,0.09$ respectively). The protocol of adjusting supplement allocation according to weekly plasma glucose concentrations was successful in that the target glucose concentration $(3.5 \mathrm{mmol} / \mathrm{l})$ for the supplemented diet was achieved (mean glucose concentration over the entire period: $3.5 \mathrm{mmol} / 1 \pm 0.12$ s.e.). The mean plasma glucose concentration for the unsupplemented treatment was $3.1 \mathrm{mmol} / \mathrm{l}( \pm 0.18$ s.e. $)$, which is surprisingly high, given that the basal diet provided energy for maintenance requirements only. The mean amount of supplement fed over the period was $315 \mathrm{~g} / \mathrm{animal} / \mathrm{d}( \pm 15$ s.e.) for Indigenous goats and $357 \mathrm{~g} / \mathrm{animal} / \mathrm{d}( \pm 54$ s.e.) for Saanen crossbreds.

Table 5 Plasma metabolite concentrations of Indigenous and Saanen x Indigenous crossbred goats

\begin{tabular}{|c|c|c|c|c|c|c|}
\hline \multirow[b]{2}{*}{ Week } & \multicolumn{2}{|c|}{$\frac{\text { Urea concentration }}{(\mathrm{mg} / \mathrm{dl})}$} & \multicolumn{2}{|c|}{$\frac{\text { Glucose concentration }}{(\mathrm{mmol} / \mathrm{l})}$} & \multicolumn{2}{|c|}{$\frac{\text { Cholesterol concentration }}{(\mathrm{mg} / \mathrm{dl})}$} \\
\hline & Indigenous & Saanen & Indigenous & Saanen & Indigenous & Saanen \\
\hline 1 & $14.3^{\mathrm{a}}(1.9)$ & $26.1^{\mathrm{b}}(2.5)$ & - & - & $57.9(3.5)$ & $66.8(4.1)$ \\
\hline 2 & $14.0^{\mathrm{a}}(1.3)$ & $24.3^{\mathrm{b}}(1.8)$ & $2.89^{\mathrm{a}}(0.15)$ & $3.71^{\mathrm{b}}(0.22)$ & $66.7(4.3)$ & $69.7(6.1)$ \\
\hline 3 & $12.3^{\mathrm{c}}(1.8)$ & $20.0^{\mathrm{d}}(2.5)$ & $2.84^{\mathrm{a}}(0.15)$ & $3.72^{\mathrm{b}}(0.21)$ & $73.8^{\mathrm{c}}(5.4)$ & $51.9^{\mathrm{d}}(7.8)$ \\
\hline 4 & $12.3^{\mathrm{a}}(1.4)$ & $24.9^{\mathrm{b}}(2.0)$ & $2.91^{\mathrm{a}}(0.15)$ & $4.20^{\mathrm{b}}(0.22)$ & $81.1^{\mathrm{a}}(4.6)$ & $56.5^{\mathrm{b}}(6.7)$ \\
\hline 5 & $10.5^{\mathrm{a}}(1.2)$ & $26.5^{\mathrm{b}}(1.7)$ & $2.76^{\mathrm{a}}(0.16)$ & $3.99^{\mathrm{b}}(0.23)$ & $79.7(6.1)$ & $59.9(9.0)$ \\
\hline 6 & $9.6^{\mathrm{a}}(0.7)$ & $19.6^{\mathrm{b}}(1.0)$ & $2.78^{\mathrm{a}}(0.09)$ & $3.79^{\mathrm{b}}(0.14)$ & $84.1^{\mathrm{c}}(5.4)$ & $64.8^{\mathrm{d}}(7.6)$ \\
\hline 7 & $10.0^{\mathrm{a}}(1.1)$ & $24.0^{\mathrm{b}}(1.5)$ & $3.07^{\mathrm{c}}(0.21)$ & $3.90^{\mathrm{d}}(0.30)$ & $89.7(5.3)$ & $71.2(7.7)$ \\
\hline 8 & $14.3^{\mathrm{a}}(1.5)$ & $27.1^{\mathrm{b}}(2.1)$ & $2.97^{\mathrm{c}}(0.10)$ & $3.44^{\mathrm{d}}(0.14)$ & $90.4^{\mathrm{c}}(5.0)$ & $68.3^{\mathrm{d}}(7.2)$ \\
\hline 9 & $14.5^{\mathrm{a}}(1.8)$ & $28.6^{\mathrm{b}}(2.6)$ & $3.12(0.14)$ & $3.58(0.20)$ & $92.7^{\mathrm{c}}(5.1)$ & $73.8^{\mathrm{d}}(7.1)$ \\
\hline 10 & $14.0^{\mathrm{a}}(1.7)$ & $32.5^{\mathrm{b}}(2.4)$ & $2.90^{\mathrm{c}}(0.11)$ & $3.39^{\mathrm{d}}(0.17)$ & $90.5^{\mathrm{a}}(3.8)$ & $71.2^{\mathrm{b}}(5.6)$ \\
\hline 11 & $13.1^{\mathrm{a}}(1.8)$ & $28.7^{\mathrm{b}}(2.5)$ & $3.05^{\mathrm{a}}(0.14)$ & $3.86^{\mathrm{b}}(0.21)$ & 87.7 (4.6) & $74.0(6.7)$ \\
\hline 12 & $9.5^{\mathrm{a}}(1.1)$ & $25.6^{\mathrm{b}}(1.5)$ & $2.96(0.10)$ & $2.88(0.14)$ & $78.0(5.6)$ & $68.6(8.0)$ \\
\hline
\end{tabular}

$\mathrm{a}, \mathrm{b}, \mathrm{c}, \mathrm{d}$ Means in the same row and within the same variable with different superscripts differ significantly: ${ }^{\mathrm{a}, \mathrm{b}}(\mathrm{P}<0.01),{ }^{\mathrm{c}, \mathrm{d}}(\mathrm{P}<0.05)$. Standard errors are given in parentheses. 
Plasma glucose and urea concentrations were higher in the Saanen crossbred genotype than in Indigenous goats, and cholesterol concentrations were lower (Table 5). There were significant breed $\mathrm{x}$ diet interactions during week 2 in the case of urea $(\mathrm{P}=0.06)$ and cholesterol $(\mathrm{P}<0.05)$ concentrations (Table 4). Plasma urea concentrations were not affected by diet in the case of the Indigenous goat $(\mathrm{P}>0.05)$ during week 2, but in the Saanen crossbred, urea concentrations increased by $45 \%$ in response to the low plane of nutrition $(\mathrm{P}<0.05)$. Plasma cholesterol concentrations increased by $27 \%$ in response to the low plane of nutrition in the Indigenous genotype $(\mathrm{P}=0.08)$ during week 2 , but were unaffected in the case of the Saanen crossbred $(\mathrm{P}>0.08)$. There were no treatment $\mathrm{x}$ genotype interactions for glucose concentrations $(\mathrm{P}>$ $0.05)$.

Because basal plasma glucose concentrations differed between genotypes (see Table 5), glucose concentrations recorded during insulin tolerance tests were expressed as a percentage of basal (pre-injection) glucose concentrations. Main effects and their interactions following insulin tolerance tests are shown in Table 6.

Table 6 Main effects of diet, breed and diet x breed interaction on plasma glucose concentrations (\% of basal concentration) following an injection of insulin in Indigenous and Saanen-crossbred goats during week 3, 7 or 11 of lactation

\begin{tabular}{|c|c|c|c|c|c|c|c|c|c|}
\hline \multirow[b]{2}{*}{$\begin{array}{l}\text { Time of } \\
\text { sample } \\
\text { (min after } \\
\text { insulin } \\
\text { injection) }\end{array}$} & \multicolumn{3}{|c|}{ Week 3} & \multicolumn{3}{|c|}{ Week 7} & \multicolumn{3}{|c|}{ Week 11} \\
\hline & Diet & Breed & $\begin{array}{l}\text { Diet } x \\
\text { Breed }\end{array}$ & Diet & Breed & $\begin{array}{l}\text { Diet } x \\
\text { Breed }\end{array}$ & Diet & Breed & $\begin{array}{l}\text { Diet } x \\
\text { Breed }\end{array}$ \\
\hline 15 & NS & NS & NS & NS & NS & NS & NS & $*$ & $*$ \\
\hline 30 & NS & $*$ & NS & NS & $* *$ & + & $*$ & $*$ & $* *$ \\
\hline 45 & NS & NS & NS & $*$ & $*$ & NS & NS & NS & $* *$ \\
\hline 60 & NS & NS & NS & $* *$ & NS & + & NS & NS & + \\
\hline 120 & NS & NS & NS & NS & NS & NS & + & NS & + \\
\hline
\end{tabular}

${ }^{+} \mathrm{P}<0.10 ;{ }^{*} \mathrm{P}<0.05 ;{ }^{* * *} \mathrm{P}<0.01 ; \mathrm{NS}$, not significant

Mean plasma glucose concentrations following insulin injection were higher in the Saanen crossbred genotype than in the indigenous genotype at 30 min post-injection during week 3, at 30 and 45 min post-injection during week 7 (e.g. Figure 4) and at 15 and 30 min post-injection during week 11 (Table 6).

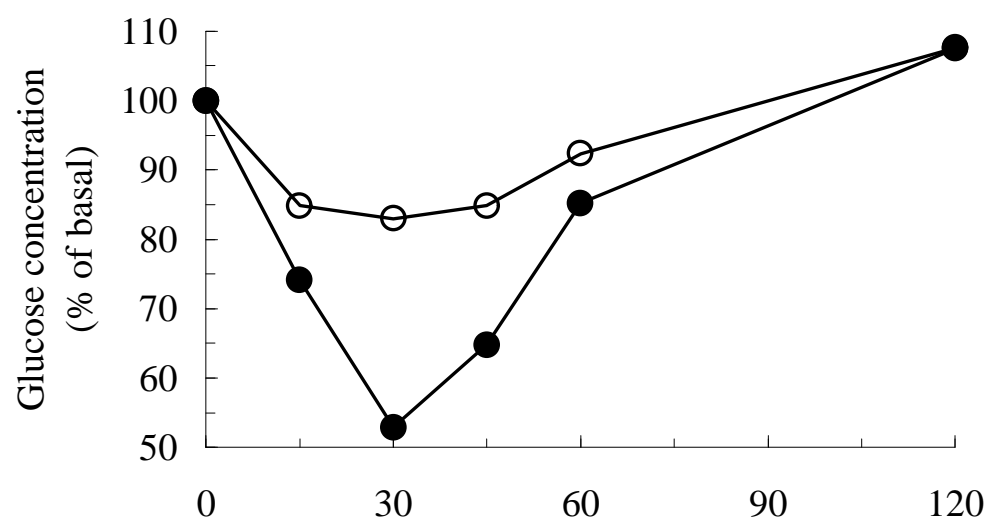

Time after insulin injection (min)

Figure 4 Plasma glucose concentrations following an intravenous insulin challenge in Indigenous $(\bullet)$ and Saanen crossbred (O) goats during week 7 of lactation 


\section{Discussion}

Milk yield was not reduced by the low plane of nutrition in either genotype. This was unexpected, as the low plane of nutrition was formulated to provide nutrients for maintenance only, with no allowance for milk production. This sustained rate of milk production was achieved by increased mobilization of endogenous nutrients from body reserves, evidenced as a greater loss of body mass at the low plane of nutrition in both breeds. The Saanen crossbred genotype, which produced twice as much milk as the Indigenous genotype, lost 19\% of initial mass by week 10 of lactation, whereas mass losses in the indigenous goat never exceeded 7\%. It would appear that the differences in milk yield observed between genotypes in this study were related to the extent to which available body reserves are mobilized to supplement dietary nutrients. Other authors have described similar responses to genetic selection for milk yield in dairy cows (McNamara, 2000; Oldham, 1999).

The partitioning of nutrients between body tissues is, to a large extent, mediated via changes in the sensitivity of muscle and adipose tissue to insulin. In meat producing animals, Hocquette et al. (1998) proposed that selection for increased growth rate was accompanied by increased insulin sensitivity, and Lobley (1998) suggested a biphasic response mechanism in which the upper and lower limits of tissue responsiveness to insulin and the growth hormone / insulin-like growth factor axis are regulated by circulating amino acid concentrations. While it is known that insulin responsiveness plays a key role in directing the partitioning of nutrients during lactation (Bell \& Bauman, 1997), no established conceptual framework exists with the same completeness as that for growth (Oldham et al., 1997), especially in respect of the effect of genetic selection. During lactation, the uptake of glucose by the insulin-dependent GLUT4 transporter in non-mammary tissues such as adipose tissue and skeletal muscle is inhibited by a reduced sensitivity to insulin in these tissues (Bell \& Bauman, 1997). This results in proportionally greater glucose uptake by the mammary gland GLUT1 transporter that is not dependent on insulin for glucose uptake. Plasma glucose concentrations were depressed to a considerably smaller extent by insulin injection in the Saanen crossbred than in the Indigenous goat at all three stages of lactation. This indicates that skeletal muscle and adipose tissues in the Saanen crossbred genotype were less sensitive to insulin than in the Indigenous genotype. This could have contributed to the higher plasma glucose concentrations and greater partitioning of nutrients to milk production observed in this genotype.

The responses discussed above provide evidence for a relatively inflexible pattern of nutrient partitioning that persists at low planes of nutrition. This suggests that genetic selection for milk production may well evoke competition between tissues. On the other hand, the existence of a genotype x nutrition interaction for several independent parameters during early lactation provides evidence of co-ordination of nutrient partitioning and deserves consideration.

In the Saanen crossbred genotype, urea concentrations were increased by $45 \%$ in response to the low plane of nutrition during early lactation (week two), suggesting that muscle protein was catabolised to provide glucose precursors in order to sustain milk production. In contrast, diet had no effect on urea concentrations in the indigenous goat, but cholesterol concentrations were elevated by $27 \%$, indicating that adipose tissue reserves were broken down as a source of non-glucogenic energy. Diet had no effect on cholesterol concentrations in the Saanen crossbred genotype. These different responses to a decrease in the plane of nutrition suggest that the two genotypes adapted nutrient partitioning according to a different set of priorities during early lactation. These patterns of blood metabolite concentrations may indicate that glucogenic precursors were mobilised from muscle protein to support a relatively higher priority for milk production in the Saanen crossbred genotype, and adipose tissue reserves were mobilised as a source of non-glucogenic energy to support a relatively higher priority for maintenance of non-mammary tissues in the Indigenous goat. This is supported by mass changes during week one of lactation: milk production was unaltered by plane of nutrition in the Indigenous goat, while in the Saanen crossbred, milk production was decreased in response to the low plane of nutrition. Although this may be indicative of an adaptive response to lower nutrition in the Saanen, it is significant to note that despite this, milk production was still $42 \%$ higher than that recorded for the Indigenous genotype.

\section{Conclusions}

The results of this study are somewhat ambiguous: although there was some evidence to indicate that the Saanen adapted milk yield in accordance with plane of nutrition during week two of lactation, this genotype $\mathrm{x}$ nutrition interaction did not persist throughout lactation. The majority of data derived from this study indicates that neither genotype adapted milk production in response to diet, with the consequence that the higher milk-yielding Saanen lost substantially more body mass the Indigenous goat. Oldham (2000) suggested that although higher-merit dairy cows are genetically inclined to use body reserves to sustain milk production to a greater extent than their lower-merit contemporaries, there is resistance to reducing body fatness below a certain level. The significance of the postulated lower limit to the extent to which body mass mobilization can be increased by selection for milk yield depends on whether this limit is attained before or after reproductive activity is compromised. There is evidence to indicate that reproduction rate is lower in dairy cattle of high 
genetic merit for milk yield (Muller et al., 1999). At the lower level of nutrition employed in this study, the extent of the mass loss in the Saanen crossbred genotype was, without doubt, similar to that which has been associated with reproductive failure under field conditions.

\section{Acknowledgements}

The assistance of M.J. Van der Linde and H.T. Groeneveld with statistical and data analysis, and that of E. Mulder with laboratory analyses is gratefully acknowledged. This research was supported by a grant from the South African Foundation for Research Development.

\section{References}

Bell, A.W. and Bauman, D.E., 1997. Adaptations of glucose metabolism during pregnancy and lactation. J. Mammary Gland Biol. and Neoplasia 2, 265-278.

Bauman, D.E., 2000. Regulation of nutrient partitioning during lactation: homeostasis and homeorhesis revisited. In: Ruminant physiology: digestion, metabolism, growth and reproduction. Ed. Cronjé, P.B., CAB International, Wallingford, UK. pp. 311-328.

Cronjé, P.B., 2000. Nutrient-gene interactions: future potential and applications. In: Ruminant physiology: digestion, metabolism, growth and reproduction. Ed. Cronjé, P.B., CAB International, Wallingford, UK. pp. 409-422.

Hocquette, J.F., Ortiques-Marty, I., Pethick, D., Herpin, P. and Fernandez, X., 1998. Nutritional and hormonal regulation of energy metabolism in the skeletal muscles of meat-producing animals. Livest. Prod. Sci. 56, 115-143.

Lobley, G.E., 1998. Nutritional and hormonal control of muscle and peripheral tissue metabolism in farm species. Livest. Prod. Sci. 56, 91-114.

McNamara, J.P., 2000. Integrating the effects of genotype and nutrition on utilization of body reserves during lactation of dairy cattle. In: Ruminant physiology: digestion, metabolism, growth and reproduction. Ed. Cronjé, P.B., CAB International, Wallingford, UK. pp. 353-369.

Muller, U., Leucht, W., Reinecke, and Dalle, T., 1999. Breeding and biological evaluation of yield selection in dairy cattle. Animal Research and Development 49, 52-62.

National Research Council, 1981. Nutrient requirements of goats. Natl. Acad. Sci., Washington DC.

Oldham, J.D., Emmans, G.C. and Kyriazakis, I., 1997. Limits and limitations to nitrogen use in farm animals. Proc. Nutr. Soc. 56, 525-534.

Oldham, J.D., 2000. Genotype x nutrition interactions in herbivores. In: Nutritional ecology of herbivores. Eds. Jung, H.G. and Fahey, G.C., American Society of Animal Science, Savoy, USA.

SAS, 1990. SAS procedure users guide version 6, third edition. SAS Institute inc., USA. 